\title{
Intellectual capital, organisational performance and competitive advantage
}

\section{Manuel Alejandro Ibarra-Cisneros}

Autonomous University of Baja California,

Baja California, Mexico

Email: manuel ibarra@uabc.edu.mx

\section{Felipe Hernández-Perlines*}

University of Castilla-La Mancha,

Castilla-La Mancha, Spain

Email: Felipe.HPerlines@uclm.es

*Corresponding author

\section{María Rodríguez-García \\ ESIC Business \& Marketing School, \\ Valencia, Spain \\ Email: maria.rodriguez.investigadorval@esic.edu}

\begin{abstract}
At present, the role of intellectual capital in organisations is significantly more important than in the past owing to the transition from an economy based on assets to another based on knowledge. The value of intangible assets increases as that of tangible assets decreases; this allows organisations, which prioritise intellectual capital, to produce competitive advantages and achieve better performance. The purpose of this paper is to ascertain if human capital, structural capital and relational capital have a positive influence on the organisational performance of medium-sized firms in the Mexican manufacturing sector. Moreover, it is analysed if competitive advantage mediates the relation between intellectual and organisational performance. Data were obtained from a survey sent to 309 CEOs of Mexican manufacturing firms. In order to test the research hypotheses, the construct validity was tried by means of face, content, convergent, nomological and discriminant validity, for which techniques such as exploratory and confirmatory factor analysis using SPSS and AMOS, respectively, were resorted to. Later on, Partial Least Squares Structural Equation Modelling (PLS-SEM) was applied using software SmartPLS. Results showed that the three dimensions of intellectual capital have a positive and significant influence on organisational performance. Furthermore, competitive advantage mediates the relation between intellectual capital and organisational performance.
\end{abstract}

Keywords: intellectual capital; competitive advantage; organisational performance; manufacture.

Reference to this paper should be made as follows: Ibarra-Cisneros, M.A., Hernández-Perlines, F. and Rodríguez-García, M. (2020) 'Intellectual capital, organisational performance and competitive advantage', European $J$. International Management, Vol. 14, No. 6, pp.976-998. 
Biographical notes: Manuel Alejandro Ibarra-Cisneros is $\mathrm{PhD}$ in Economics and Labour Relations. He works in the Faculty of Administrative Sciences in the Autonomous University of Baja California, Mexico. His research topics are intellectual capital, entrepreneurial orientation, IT adoption, human resources, labour flexibility, international economics, geopolitics and absorptive capacity. $\mathrm{He}$ is author of several research articles, book chapters, and master's and doctoral thesis director.

Felipe Hernández-Perlines is $\mathrm{PhD}$ in Economics and Business. He is a Professor of Strategic Management in the Department of Business Administration at the University of Castilla-La Mancha (Spain). He has been a visiting professor at universities in Italy, France, Mexico and the USA. His research has focused on agri-food cooperatives, family businesses and the tourism sector. His work has been published in journals such as Journal Business Research, R\&D Management, European Journal of International Management, Psychology \& Marketing, Frontiers in Psychology, Management Decision, International Journal of Contemporary Hospitality Management and International Journal of Hospitality Management.

María Rodríguez-García is a PhD student in Business Administration at the University of Valencia (Spain). Her research is focused in the entrepreneurship line of research, highlighting green entrepreneurship. On the other hand, she is advancing in family firms research. Among her research projects we can stand out SPRING (Succession Planning and Regeneration In Family Businesses for New Growth), a project under the light of the European Union in which the University of Valencia acts as a partner; and collaboration in the academic scope for INEKA Conference. She is Editorial Assistant of International Journal of Intellectual Property Rights and Collaborator at the Chair "Entrepreneurship: Being student to entrepreneur"-Grupo Maicerías EspañolasArroz DACSA and the Faculty of Economics (Valencia).

\section{Introduction}

Indubitably, all tangible assets are relevant for firms; they are utilised to produce goods and services for clients, they are found in the balances and being visible for everyone, they are deemed highly valuable for shareholders, clients and suppliers. However, there are also intangible elements that contribute to growth, development and organisational performance (OP), which are called intellectual capital (IC).

Bueno et al. (2014, p.344) state that "the terminology utilized in the development of IC is excessively scientific and technical when there is a limited entrepreneurial culture, hence in cases like this, firms do not understand it." If this is the case, it is likely that firms are not fully exploiting their intangibles; consequently, they do not quantify them and, thereby, do not monetise them. For its part, the academic world has made relevant contributions to the study of IC (Kaplan and Norton, 1992; Brooking, 1996; Edvinsson and Malone, 1997; Roos and Roos, 1997; Nahapiet and Goshal, 1998) and its dimensions: human capital (HC), structural capital (SC) and relational capital (RC). In virtue of the advances in the study of IC, firms have acquired knowledge, but manly have become aware of the impact of IC on OP.

Additionally, complementary research lines have been developed. In them, a number of variables have been included to analyse how they influence the aforementioned 
relation; one of them is competitive advantage (CA). Various authors (Kong and Prior, 2008; Sirmon et al., 2008; Kamukama et al., 2011; Yaseen et al., 2016; Ferreira and Fernandes, 2017; $\mathrm{Li}$ and $\mathrm{Yu}, 2018$ ) have contributed to demonstrate how CA positively influences IC and/or OP. In this sense, Yaseen et al. (2016, p.170) comment that "intellectual capital provides resources and capabilities to create a sustainable competitive advantage in firms." Therefore, it is very important that the firms identify the mechanisms that potentialise intellectual capital, be aware of which competitive advantages they have, and thus discover if all this allows increasing their organisational performance.

In Mexico, the manufacturing sector is one of the most dynamic in the country; it contributed with $15.8 \%$ to GDP and generated more than 3 million job posts (INEGI, 2018a). Additionally, this sector is the one that applies the most technology, promotes the development of human capital and forges important alliances with clients and suppliers. This sector actively participates in international value chains through its most important clusters, including the automotive, auto parts, aerospace, medical devices, electronic, household appliances and processed foods (PROMEXICO, 2018). For these reasons, this sector was chosen to be a research subject.

The purpose of this paper is to ascertain if human capital, structural capital and relational capital have a positive influence on organisational performance in mediumsized firms of the Mexican manufacturing sector. Besides, it is analysed how competitive advantage mediates the relation between intellectual capital and organisational performance. Finally, it is established if the origin of capital and exporting activity have a moderating role between IC and OP.

The first part of the document is devoted to a review of the literature, in particular the topics of intellectual capital and its three dimensions are analysed as well as organisational performance and competitive advantage, and also the research hypotheses are formulated. In the second part, the research methodology is presented, for which a survey based on the studies of the authors (Bontis et al., 2000; Li et al., 2006; Sharabati et al., 2010; Kamukama et al., 2011; Phusavat et al., 2011; Kamukama, 2013; Khalique et al., 2015) was designed and applied to CEOs and managers of medium-sized manufacturing firms.

In the third part, the results of the research are presented by verifying the validity of the construct with face, convergent, nomological and divergent validity tests. To do so, an exploratory factor analysis was carried out using statistical software SPSS, ver. 22. Later on, a confirmatory factor analysis was run utilising AMOS, and Partial Least Squares Structural Equation Modelling was applied using software SmartPLS. Finally, in the last part of this document, the discussion and conclusions are developed and the implications, contributions and limitations of the research are presented.

\section{Literature review}

\subsection{Intellectual capital}

Intellectual capital can be defined as all those intangibles an organisation has and which can be acquired or generated, assimilated, processed and implemented in a harmonious way in order to attain higher levels of innovation, productivity and competitiveness, in spite of not being reflected in the financial statements. Moreover, they produce future 
value, upon which competitive advantage rests (Sánchez Medina et al., 2007; Zhang et al., 2018). Therefore, the purpose of IC research is to analyse all the intangibles that exist in an organisation (Torres et al., 2018). Likewise, IC is considered to be dominated by the organisation's ability to transform one resource into another (Peng et al., 2007). Hence, it is not only about owning IC, but also about how this allows the organisation to generate even more. Asiaei and Jusoh (2017, p.3) comment that "the literature shows that intellectual capital comprises various types of knowledge-based assets," so it is very important that the organisation can clearly identify them in order to process them. A more strategic use of IC requires reinforcement of training, professionalisation and cooperation within the organisation (Fernández-Jardón and Martos, 2016). In like manner, Yaseen et al. (2016, p.170) argue "that organizations can substitute tangible assets and resources, but they are unlikely to do that with intangible assets."

On the other hand, Pedro et al. $(2018$, p.438) state that "the importance and positive impact of IC on the performance of organizations is confirmed, as well as the advantages of efficient assessment for their development and growth." In this sense, Pitchayadol et al. (2018), Dabić et al. (2018) and Jardon and Martos (2012) also argue that IC is more important as a source of competitive advantage in SMEs because tangible resources are often fewer. This explains why the impact is heavier on SMEs that take advantage of their IC.

IC can be divided into different dimensions depending on the author which uses it; for instance, Youndt et al. (2004) divide IC into human, social and organisational. Whereas, Bueno et al. (2011) divide it into human, organisational, technological, social, customer and business. However, the most popular classification was the earliest developed, in which IC is only divided into three dimensions: human, structural and relational (Bontis, 1998; Seetharaman et al., 2004; Seleim et al., 2004; Chu et al., 2006). In this paper, we decided to resort to this classification because it is the most used in the literature.

There are several methods to measure IC in organisations. Most authors choose to make use of qualitative indicators (Bontis et al., 2000; Díez et al., 2010; Sharabati et al., 2010; Phusavat et al., 2011), as in the case of this paper, since these indicators can analyse variables that organisations are unlikely to be able to measure; while others prefer to use quantitative and financial indicators. In this regard, a number of metrics have been used over the last 20 years (Liebowitz and Suen, 2000); for example, Ståhle et al. (2011) demonstrated that the Value Added Intellectual Capital Coefficient (VAIC) is not a good method to measure intellectual capital, which evinces there is neither single methodology nor general consensus about what the best one is; albeit, qualitative indicators are taking the lead in recent studies. In like manner, organisational performance measurement models should be better exploited when there is high IC in them (Asiaei and Jusoh, 2017).

Bueno et al. (2014) mention there is a huge gap between theory and practice when IC is analysed in all kind of organisations. It is difficult to understand what IC means and how it can be measured; thereby, not all the intangibles are considered or sometimes they are not treated with the same importance as others. It is also true that depending on the area of the company the intensity in the use of a certain IC may vary (Lynn and Dallimore, 2004; Youndt et al., 2004; Díez et al., 2010); an example of this is relational capital, which is more important in the area of customer service, where structural capital mostly prevails. This way, the measurements used can be more specific if they include a combination of quantitative and qualitative indicators. 


\subsubsection{Human capital}

Human capital can be defined as the knowledge acquired by the members of an organisation, their productivity, and the value of their contribution to the company (Montejano and López, 2013; Lee and Lee, 2018). HC can be internally developed or attracted, looking for people with vast knowledge and honed skills in the external labour market (Youndt et al., 2004). Ali et al. (2018) and Kianto et al. (2010) consider that HC is the most important of all capitals. For their part, Jardon and Martos (2012, p.476) comment that the process of producing intellectual capital begins with human capital. In this sense, Stieg et al. (2018) and Ugalde-Blinda et al. (2014) mention that HC is vital for SMEs to attract talent and thus achieve the organisation objectives. Han and Li (2015) mention that firms with abundant human capital can find it easier to anticipate changes in the environment and can be more efficient in their communication and faster to grasp opportunities and avoid threats; however, if they lack human capital, such capabilities cannot be properly developed, which will affect the firms' performance. HC comprises all the knowledge (explicit and tacit), capabilities and skills of the organisation workers (Gashi et al., 2017); it also includes attitude (behaviour, motivation and ethical conduct) and intellectual agility (innovation, imitation and adaptation) (Kang and Snell, 2009). Galabova and McKie (2013) include individual competence, personal networks, health, work ability and experience gained over the years.

\subsubsection{Structural capital}

Structural capital refers to all the knowledge owned by an organisation and that is independent from the people. In this sense, it is the set of intangibles that structure and develop the activities of the organisation (Uriona et al., 2013). On the other hand, Ramírez and Duván (2007, p.140) comment that SC "represents the knowledge that the organization accomplishes to make explicit, systematize and internalize and which, at first, can be latent in the people and teams of the firms." SC can be conceptualised in different ways depending on the preference to analyse innovation or productive processes (Chang et al., 2013). Moreover, SC is the critical link that allows IC to be measured at the organisational level of analysis (Bontis et al., 2000). For their part, Scarabino et al. (2007, p.64) argue that structural capital will adapt faster and will be recognised in accountancy as it is the best positioned to reach the scientific rigour necessary for its assessment, registration and accounting exposition. SC comprises relations (including strategic networks, alliances, relationships with customers and other key stakeholders), organisation (databases, operation manuals, strategies, organisational charts, routines, infrastructure, processes and culture), renewal and development (research and development, investments in organisational learning), mechanisms, structures and anything whose value for the company is worthier than its material value (Bontis et al., 2000; Bollen et al., 2005; Moon and Kym, 2006; Tovstiga and Tulugurova, 2007).

\subsubsection{Relational capital}

Relational capital is the part of intellectual capital that allows creating value as regards the external relations of the company (Edvinsson and Malone, 1997; Scarabino et al., 2007; Walecka, 2018). Sánchez Medina et al. (2007, p.106) state that "RC is drawn on the consideration that companies are not isolated systems, but, on the contrary, are related to the outside." On the other hand, Jain et al. (2017) argue that 'from the perspective of RC, SMEs acquire more knowledge from their customers because of the 
close proximity and are able to develop their RC with greater ease'. RC consists of alliances and partnerships, brand image, business collaborations, community relations, competitors, consumer trust, corporate reputation, customer loyalty and relationships, customer satisfaction, distribution agreements, distribution channels, joint ventures, knowledge of marketing channels, licensing agreements, networking systems, partnerships, social networks and supplier relations (Bollen et al., 2005; Kianto et al., 2010; Cricelli et al., 2014).

\subsection{Organisational performance}

Several papers have been produced in order to analyse the influence between intellectual capital and organisational performance (Nahapiet and Ghoshal, 1998; Bollen et al., 2005; Tseng and James, 2005; Wang and Chang, 2005; Suraj and Bontis, 2012; Liang et al., 2013; Khan and Terziovski, 2014; Wang et al., 2014; Cleary and Quinn, 2016; Agostini et al., 2017; Alfraih, 2018; Asiaei et al., 2018; Bontis et al., 2018; Cabrilo and Dahms, 2018; Hamdan, 2018; Nadeem et al., 2018; Kengatharan, 2019). The results of many of them have been positive, as they show that IC positively and significantly influences OP, either in all or at least in some of the IC dimensions. Organisational performance consists of those indicators that allow the management to find out if the expected results are being obtained from a quantitative and qualitative standpoint. In this sense, organisations can decide on the actions that should be implemented to improve performance; this way, their measurement is essential for every organisation and the success or failure of a firm can depend on it. Likewise, it should also be considered that in addition to analyse the effect that tangible assets have on the organisation, it is also necessary to consider intangible assets, in this case intellectual capital. We concur with Phusavat et al. (2011) on the fact that measuring financial and non-financial performance should be the prerequisite for any organisation.

Regarding the use of financial indicators, Gogan et al. (2016) point out that such indicators are found in the information contained in the companies' balance sheets, income statements and tax reports, among others. That is, it focuses on information that the firm specifically knows; therefore, they are considered indicators the firm always processes. In this respect, there are several studies that show the relation between IC and OP measured via financial indicators (Ginesti et al., 2018; Hamdan, 2018). For their part, Mercado et al. (2012) comment that although the use of financial indicators does not always fully belong to IC measurement, such indicators are still relevant and influence the competitiveness of organisations.

On the other hand, Delaney and Huselid (1996) point out that non-financial indicators are composed of perceptions generated both inside and outside the organisation. Among the most important indicators we find comparing the organisation with respect to itself over a period of time, the quality of services or products, customer satisfaction and suppliers, work environment, among others. In this sense, Pirozzi and Ferulano (2016) argue that it is also necessary to assess the performance from the standpoint of management and its leadership, which should be able to properly use human resources and all processes within the organisation.

For this research, we chose to use non-financial indicators according to the existing literature, where this type of indicator is considered the most appropriate to analyse organisational performance (Bontis, 1998; Bollen et al., 2005; Phusavat et al., 2011). 


\subsection{Competitive advantage}

From the classic definitions of competitive advantage by Porter (1980), and subsequent systemic competitiveness by Rusu and Roman (2018) and Esser et al. (1996), many authors have studied how competitiveness is gained in an organisation. Besides, there is a group of studies that focus on demonstrating what the relationship between intellectual capital, organisational performance and/or competitive advantage is (Kong and Prior, 2008; Sirmon et al., 2008; Tovstiga and Tulugurova, 2009; Kamukama et al., 2011; Kamukama, 2013; Jurksiene and Pundziene, 2016; Yaseen et al., 2016; Ferreira and Fernandes, 2017; Yu et al., 2017). Porter (1991) claims that the competitiveness of a nation is due to the fact that its firms are highly productive thanks to the efficient use of their human, natural and capital resources. That is, a relation between IC is established as an essential part to attain competitive advantage. Besides, Abdel and Romo (2004) emphasise that entrepreneurial competitiveness comes from the competitive advantage a firm has from its production methods and organisation (reflected in prices and quality of the final product) in relation to its competitors in a specific market. Berumen (2006) mentions that competitiveness in the firms is related to prices, costs, quality of the products and the incorporation of technological improvements into the processes. In this sense, Rua et al. (2018) comment that CA can be derived from differentiation and cost leadership. In the case of Schilke (2014, p.188) the variable competitive advantage is operationalised by means of strategic performance (qualitative dimension) and financial performance (quantitative dimension). Finally, Jardon and Martos (2012) point out that IC may be a source of competitive advantage if it combines with the firm's organisational capabilities. For their part, Li et al. (2006) underscore that organisational performance is influenced by competitive advantage.

After the literature review, the following hypotheses are proposed:

H1: Human capital has a positive influence on organisational performance in the Mexican manufacturing sector.

H2: Organisational performance in Mexican manufacturing firms is positively influenced by structural capital.

H3: Relational capital has a positive influence on organisational performance in Mexican manufacturing firms.

H4: The origin of capital positively moderates the relation between intellectual capital and organisational performance.

H5: Exporting firms positively moderate the relation between intellectual capital and organisational performance.

H6: Competitive advantage mediates the relation between intellectual capital and organisational performance.

\section{Methodology}

In order to respond to the research hypotheses, the sample was determined in the first place, for which the population of manufacturing firms registered in the country was 
quantified. This population accounted for 529,607 out of a total of 5,078,735 firms that existed in Mexico in 2016 (INEGI, 2018b); that is, the manufacturing sector represents $10.42 \%$ of the national productive apparatus.

For the purposes of this study, only medium-sized firms were included $(8.064 ; 1.5 \%$ of the total); these are firms with a range of employees between 51 and 250; this firm size was chosen as they have a formal organisational structure and specific roles inside the organisation. To define the sample size a confidence level of $95 \%$ and an error margin of $5 \%$ were considered, which turned into 367 firms, out of which 309 surveys $(84.20 \%)$ were successfully answered.

The surveys were designed in electronic format, for which an own webpage was designed, the survey was sent to all the CEOs and managers of the firms in the country via email using data from DENUE (National Statistical Directory of Economic Units) produced by the National Institute of Statistics and Geography (INEGI, 2018b), which comprises all the firms in the country and is periodically updated. Likewise, it was tried as much as possible that all the manufacturing activities were included in the sample (Table 1). Since non-sampling errors can occur at any point of the research, the following measures were taken in order to reduce such error to a minimum: (1) the drafting of the questions was checked with experts to avoid confusion, besides the pilot test undertaken was very useful to improve drafting; (2) only the surveys answered by CEOs and managers were considered; (3) the respondents were given an email to ask any question or make a request; (4) the coherence in the response was verified to avoid contradictions in the information; and (5) occasional phone calls were made to some firms to verify that the survey had been answered by the right person.

A 76-item survey was designed using important contributions from previous research (Bontis et al., 2000; Li et al., 2006; Sharabati et al., 2010; Kamukama et al., 2011; Phusavat et al., 2011; Kamukama, 2013; Khalique et al., 2015). The survey was divided into four sections. The first was composed of several questions to identify the company (name, location, city, state, economic activity, age and origin of capital). The second section was designed using answers in a five-point Likert scale (from $1=$ strongly disagree to $5=$ strongly agree) to measure the items from different indicators that make up intellectual capital, which are human, structural and relational. The third section was also designed using a five-point Likert scale, but with different answers (from 1 = below to 5 above), which was used to analyse the variable of organisational performance via non-financial indicators.

Competitive advantage was integrated as a mediating variable, for which a five-point Likert was also used (from $1=$ strongly disagree to $5=$ strongly agree), as in the second section, this variable was based on indicators developed by $\mathrm{Li}$ et al. (2006), which are price, cost, product quality, product innovation, time to market and delivery dependability (Table 2).

Additionally, two questions that served as moderating variables were added; in this case, they were origin of capital $(1=$ foreign; $0=$ national $)$ and exporting activity - if the firm exports to other countries $(1=$ yes; $0=$ no). The aim of these variables was to find out if there is a moderating effect on firms with foreign capital or exporting activities in the relation between IC and OP. Ritchie (2002) states that foreign firms - multinational in this case - in addition to transfer knowledge and human capital training to the recipient countries, improve abilities as well and produce knowledge via spill-over effect and further competitiveness. Under this scheme, in the present paper it is intended to find out 
if foreign-capital firms positively and significantly influence the relation between intellectual capital and organisational performance in manufacturing firms. Furthermore, Calix et al. (2015) propose that firms with exporting activities have a higher level of intellectual capital and this, at once, allows having higher probability to acquire competitive advantages. If this is so, it would be expected that manufacturing firms with exporting activity will influence the relation between IC and CA.

In view of producing reliable results, the validity of the construct was verified by means of the following sorts of validation: face, content, convergent, nomological and discriminant resorting to exploratory and confirmatory factor analysis. Later on, with the obtained results Partial Least Squares Structural Equation Modelling was performed with sorfware SmartPLS, which also allows validating the model.

To verify that the instrument and later results were valid, a reliability test was carried out; to do so, the internal consistency measurement test was resorted to. Internal consistency measures consistency inside the instrument and ask how well a set of elements measures a behaviour or particular characteristic in the test (Drost, 2011, p.111). In this paper, Cronbach's $\alpha$ was used at a first approximation, and it was later corroborated with composite reliability in order to verify the constructs' reliability.

Table 1 Percentage of Mexican manufacturing firms in the sample applied

\begin{tabular}{lc}
\hline Manufacturing activity & Percentage of sample applied (\%) \\
\hline Food industry & 7.7 \\
Beverages and tobacco & 5.6 \\
Textile mills & 1.2 \\
Textile products & 6.4 \\
Apparel & 6.8 \\
Leather and related products & 4.5 \\
Wooden products & 0.1 \\
Paper & 6.2 \\
Printing and related activities & 1 \\
Oil and coal products & 0.1 \\
Chemical & 0.5 \\
Plastic and rubber products & 6.3 \\
Non-metallic mineral products & 2 \\
Primary metals & 1.2 \\
Metal-made products & 7.5 \\
Machinery & 8.7 \\
Computer and electronic products & 10.5 \\
Electrical equipment, appliances and components & 9.2 \\
Transportation equipment & 8.2 \\
Furniture and related products & 0.7 \\
Miscellaneous manufacturing & 5.6 \\
\hline
\end{tabular}


Table 2 Indicators included in the design of the survey

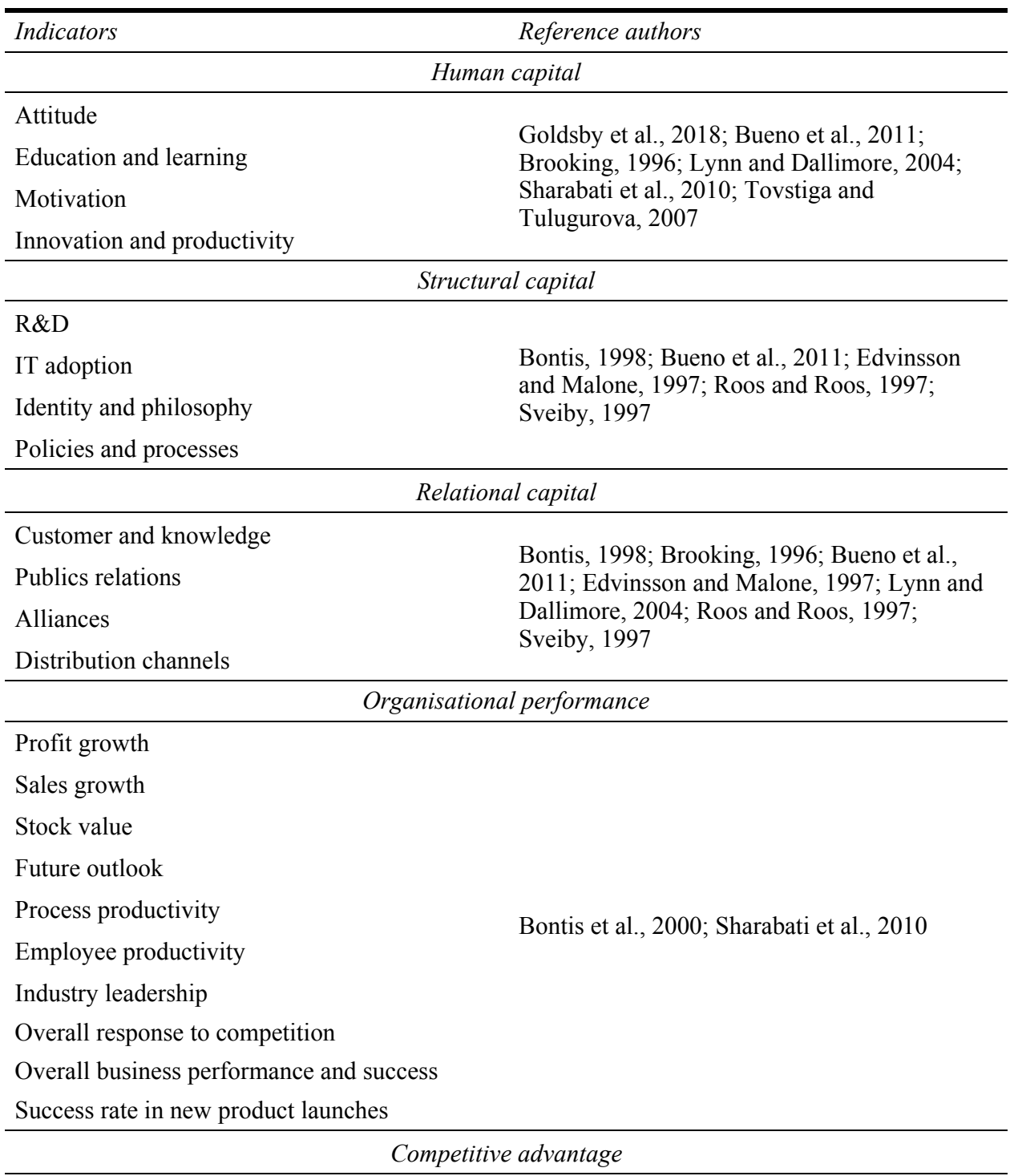

Cost/price

Quality and product innovation

Time to market

Li et al., 2006

Delivery dependability

\section{Results}

As a first stage, face validity was carried out by means of the analysis of various studies on the topics presented in this paper, which served as the basis to develop the survey. The 
items considered were those that better adapted to the processes of manufacturing firms and which additionally explain each of the established constructs.

As a second stage, content validity was developed (Sireci, 1998), to do so the results of the pilot test applied by the authors were analysed and contrasted with observations from the surveyed CEOs to make adjustments to the questions and thus measure what is intended with each construct. Although the utilised items that belong to varied contexts of different countries, these were justified from the standpoint that they were designed for medium-sized manufacturing firms. What is more, the original design does correspond to the activities developed by Mexican manufacturing firms. The obtained results suggested that the instrument was clear, accurate and it measured what each construct had to.

Data were processed with software SPSS, version 22, at a third stage. A debugging of the database was performed in order to eliminate abnormal data, duplicates and any error that might affect the results. To test the statistical validity of the previously defined constructs according to the literature reviewed, an Exploratory Factor Analysis (EFA) was applied.

EFA allowed comparing the consistency of the designed constructs in relation to previous researches (Vallejo, 2013). The results of EFA corroborated the originally established constructs (see Table 3); however, four items were eliminated owing to the low loading factor they presented, which was lower than .400 (Vallejo, 2013). The HC dimension lost one item that corresponded to the 'Attitude' indicator, this way, HC went from 18 to 17 items. On the other hand, SC, which originally had 21 items, lost three, one corresponding to 'IT adoption', another to 'Identity and philosophy' and one more to 'Policies and processes'. The rest of the constructs retained their original items $(\mathrm{RC}=18$, $\mathrm{OP}=10$ and $\mathrm{CA}=9$ ). Additionally, when analysing data in Table 3, it is noticed that all the dimensions had a Cronbach's $\alpha$ higher than .700 (Vehkalahti, 2000), thus allowing the corroboration of the model's internal consistency.

The Kaiser-Meyer-Olkin (KMO) estimator was also positive, underscoring CA and $\mathrm{SC}$ as the most important; moreover, the explained variance was also adequate (Albright et al., 2008), albeit a little low for OP and very high for CA. In the same way, the rest of the results are positive and the development of a Confirmatory Factor Analysis (CFA) was considered now using software AMOS with the purpose of making the model more robust and guaranteeing reliable results.

Table 3 Confirmatory Factor Analysis results using SPSS

\begin{tabular}{lccccc}
\hline Indicators & Cronbach's $\alpha$ & KMO & $X^{2}$ & $\bar{X}$ & \% Variance \\
\hline Human capital & 0.907 & 0.893 & 2868.7 & 3.61 & 63.77 \\
Structural capital & 0.948 & 0.931 & 5292.88 & 3.31 & 63.29 \\
Relational capital & 0.881 & 0.844 & 2517.22 & 3.59 & 62.34 \\
Organisational performance & 0.906 & 0.896 & 1720.74 & 4.01 & 54.85 \\
Competitive advantage & 0.967 & 0.922 & 3523.42 & 2.81 & 93.34 \\
\hline
\end{tabular}

The results obtained after CFA were significant, as the indicators were within the established parameters (see Table 4). The HC dimension with 17 items, after CFA, decreased to 11, in which the indicators 'Attitude' and 'Education and learning' were the most affected. All the models fit indices were found within the established parameters (Cangur and Ercan, 2015), for HC, CFA indices were: RMSEA: .060; AGFI: .924; CFI: 
.976; GFI: .962; NFI: .955; TLI: .959. Dimension SC with 18 items dropped six distributed between its four indicators; however, the indices for SC were: RMSEA: .056; AGFI: .910; CFI: .975; GFI: .949; NFI: .952; TLI: .963. Dimension RC dropped six items also between its four indicators, the indices also were strong: RMSEA: .051; AGFI: .927; CFI: .974; GFI: .959; NFI: .944; TLI: .960. OP retained its original 10 items also with positive indices: RMSEA: .052; AGFI: .941; CFI: .987; GFI: .971; NFI: .972; TLI: .978. The mediating variable $\mathrm{CA}$ also retained its nine items and with excellent indices: RMSEA: .020; AGFI: .968; CFI: .999; GFI: .994; NFI: .998; TLI: .999. Finally, the general model fit was strong: RMSEA: .059; AGFI: .911; CFI: .975; GFI: .955; NFI: .954; TLI: .957. Moreover, nomological validity was carried out by means of a chisquared test (Anderson and Gerbing, 1988), verifying the model's validity.

Table 4 Items eliminated after model fit

\begin{tabular}{lcc}
\hline Indicators & Original items & Final items \\
\hline Human capital & 18 & 11 \\
\hline Attitude & 7 & 3 \\
Education and learning & 5 & 2 \\
Motivation & 3 & 3 \\
Innovation and productivity & 3 & 3 \\
\hline Structural capital & 21 & 12 \\
\hline R\&D & 4 & 2 \\
IT adoption & 5 & 2 \\
Identity and philosophy & 5 & 3 \\
Policies and processes & 7 & 5 \\
\hline Relational capital & 18 & 12 \\
\hline Customer and knowledge & 7 & 6 \\
Publics relations & 4 & 2 \\
Alliances & 4 & 2 \\
Distribution channels & 3 & 2 \\
Organisational performance & 10 & 10 \\
Competitive advantage & 9 & 9 \\
\hline
\end{tabular}

In order to test the hypothesis formulated and establish convergent and divergent validity, we decided to use Partial Least Squares Structural Equation Modelling (PLS- SEM) through the statistical program SmartPLS version 3.2.7 (Ringle et al., 2015). PLS-SEM is justified for this research because it has important attributes such as the use of non-normal data; it can be used in small sample sizes; and it can measure formative and reflective constructs (Hair et al., 2014).

The first step using SmartPLS was to create the path model to show the indicators, dimensions and the relation between dependent and independent variables. Next step, carry out the assessment of the outer model for reflective indicators. For this, the internal consistency was evaluated through Cronbach's $\alpha$ and composite reliability (CR) (Roldán and Sánchez-Franco, 2012).

The results of internal consistency showed that Cronbach's $\alpha$ in all the dimensions was higher than the threshold of .700 , so the first indicator is positively fulfilled. 
Regarding composite reliability, Hair et al. (2014, p.111) state that "CR provides a more appropriate measure of internal consistency reliability than Cronbach's $\alpha$, because CR does not assume that the indicator loadings are equal in the population, and because Cronbach's $\alpha$ is also sensitive to the number of items in the scale and generally tends to underestimate internal consistency reliability.

In Table 5, it is noticed how all the indicators were superior to .700 in compliance with the established parameters. On the other hand, the results for convergent validity indices were positive as well, all the resultant indicators such as average variance extracted (AVE) were higher than .50 to be considered (Fornell and Larcker, 1981), while the factor loadings must be above .707 (Carmines and Zeller, 1979), there was only one item that approached the minimum threshold and therefore it was decided to eliminate it from the model.

Table 5 Reliability and convergent validity

\begin{tabular}{|c|c|c|c|c|c|c|}
\hline Construct & Items & Loadings & Cronbach's $\alpha$ & Rho_A & $A V E$ & $C R$ \\
\hline \multirow{4}{*}{ Human capital } & Attitude & 0.868 & \multirow{4}{*}{0,802} & \multirow{4}{*}{0,802} & \multirow{4}{*}{0,631} & \multirow{4}{*}{0,871} \\
\hline & Education & 0.761 & & & & \\
\hline & Innovation & 0.743 & & & & \\
\hline & Motivation & 0.882 & & & & \\
\hline \multirow{4}{*}{$\begin{array}{l}\text { Structural } \\
\text { capital }\end{array}$} & IT adoption & 0.82 & \multirow{4}{*}{0,849} & \multirow{4}{*}{0,862} & \multirow{4}{*}{0,688} & \multirow{4}{*}{0,898} \\
\hline & Identity & 0.836 & & & & \\
\hline & Procedures & 0.881 & & & & \\
\hline & Research & 0.777 & & & & \\
\hline \multirow{4}{*}{$\begin{array}{l}\text { Relational } \\
\text { capital }\end{array}$} & Alliances & 0.714 & \multirow{4}{*}{0,721} & \multirow{4}{*}{0,721} & \multirow{4}{*}{0,523} & \multirow{4}{*}{0,813} \\
\hline & Channels & 0.815 & & & & \\
\hline & Customer & 0.761 & & & & \\
\hline & Public relations & 0.786 & & & & \\
\hline \multirow{10}{*}{$\begin{array}{l}\text { Organisational } \\
\text { performance }\end{array}$} & DO1 & 0.786 & \multirow{10}{*}{0,908} & \multirow{10}{*}{0,91} & \multirow{10}{*}{0,548} & \multirow{10}{*}{0,924} \\
\hline & DO2 & 0.749 & & & & \\
\hline & DO3 & 0.719 & & & & \\
\hline & DO4 & 0.674 & & & & \\
\hline & DO5 & 0.728 & & & & \\
\hline & DO6 & 0.720 & & & & \\
\hline & DO7 & 0.741 & & & & \\
\hline & DO8 & 0.800 & & & & \\
\hline & DO9 & 0.781 & & & & \\
\hline & DO10 & 0.789 & & & & \\
\hline
\end{tabular}

The next step was to analyse discriminant validity (DV). According to Hair et al. (2014), DV 'represents the extent to which the construct is empirically distinct from other constructs or, in other words, the construct measures what it is intended to measure'. The results (Table 6) showed that the constructs share more variance with their own indicators than with indicators of other constructs. Therefore, the results are accepted. Likewise, a cross-loading analysis of the indicators was carried out, and in all of them the 
results corroborated that each indicator belongs to the dimension which they originally represented (Kock, 2012). HTMT was also calculated to analyse discriminant validity (Table 7), results indicated that values of the HTMT ratio are under .85 (Henseler et al., 2015).

Evaluating the inner model: for this, an analysis was first carried out to detect possible problems of collinearity in the inner model (Diamantopoulos and Winklhofer, 2001; Meyers et al., 2006). All the data were found within the accepted parameters since the values were in the range between 2.034 and 2.946 (Hair et al., 2017). The coefficient of determination $\left(\mathrm{R}^{2}\right)$ for the model was .485 , which means that its explanatory power is moderate according to Hair et al. (2011) $(.75=$ substantial; $.50=$ moderates; $.25=$ weak $)$ or Chin (1998) $(.67=$ substantial; $.33=$ moderate; $.10=$ weak $)$.

Table 6 Discriminant validity

\begin{tabular}{lcccc}
\hline & $\begin{array}{c}\text { Human } \\
\text { capital }\end{array}$ & $\begin{array}{c}\text { Organisational } \\
\text { performance }\end{array}$ & $\begin{array}{c}\text { Relational } \\
\text { capital }\end{array}$ & $\begin{array}{c}\text { Structural } \\
\text { capital }\end{array}$ \\
\hline Human capital & 0.794 & & & \\
Organisational performance & 0.613 & 0.741 & & \\
Relational capital & 0.644 & 0.598 & 0.723 & \\
Structural capital & 0.772 & 0.655 & 0.692 & 0.829 \\
\hline
\end{tabular}

Table 7 Ratio heterotrait monitrait (HTMT)

\begin{tabular}{lcccc}
\hline & $\begin{array}{c}\text { Human } \\
\text { capital }\end{array}$ & $\begin{array}{c}\text { Organisational } \\
\text { performance }\end{array}$ & $\begin{array}{c}\text { Relational } \\
\text { capital }\end{array}$ & $\begin{array}{c}\text { Structural } \\
\text { capital }\end{array}$ \\
\hline $\begin{array}{l}\text { Human capital } \\
\text { Organisational } \\
\text { performance }\end{array}$ & 0.704 & 0.716 & 0.836 \\
$\begin{array}{l}\text { Relational capital } \\
\text { Structural capital }\end{array}$ & 0.833 & & \\
\hline
\end{tabular}

Cross-validated redundancy (Q2) was used to measure the predictive relevance of the inner model, Q2 had a value of .246 which means a medium-high predictive level (Chin, 1998).

On the other hand, path coefficient analysis $(\beta)$ showed positive but weak relations between independent variables (HC, SC and $\mathrm{RC}$ ) and one dependent variable (OP) (Table 8). The relation between $\mathrm{HC}$ and OP was the weakest $(\beta=.202, t=2.717$, $p$ : .007); however, the relation between SC and OP was the best but modest $(\beta=.335$, $t=4.477, p: .000)$; the relation between RC and OP was also positive but weak $(\beta=.236$, $t=3.718, p: .000)$. With all this information, it is concluded that $\mathrm{H} 1, \mathrm{H} 2$ and $\mathrm{H} 3$ are accepted, for in spite there is a low level of influence, they are positive and significant.

Table 8 Model results

\begin{tabular}{lccc}
\hline Path & Path coefficient $(\beta)$ & T statistics & P values \\
\hline Human capital $\rightarrow$ Organisational performance & 0.202 & 2.717 & 0.007 \\
Relational capital $\rightarrow$ Organisational performance & 0.236 & 3.718 & 0.000 \\
Structural capital $\rightarrow$ Organisational performance & 0.335 & 4.477 & 0.000 \\
\hline
\end{tabular}


In order to test $\mathrm{H} 4$ and $\mathrm{H} 5$, the next stage of the research was to verify the moderating effect of the variables origin of capital and exporting activity on the existing relation, already individually proven, intellectual capital has with organisational performance. For which the variable IC was created on the basis of dimensions HC, SC and RC. When generating the results through the same statistical program, these showed non-significant indicators for exporting activity $(\beta=.014, \mathrm{t}=.196, p: .844)$ and origin of capital $(\beta=-.036, t=2.612, p: .541)$. This way, $\mathrm{H} 4$ and $\mathrm{H} 5$ were rejected.

Finally, in order to test H6, a mediating effect analysis was run (Table 9). Through bootstrapping, the results indicated that there is a positive and significant direct effect between CA-IC and IC-OP; that is to say, to the extent that IC has an improvement in the firms, OP strengthens. The same situation takes place in the relationship between IC and $\mathrm{CA}$. However, the direct effect between $\mathrm{CA}$ and $\mathrm{OP}$ was not significant; therefore, CA does not affect OP by itself. H6 is accepted owing to the positive and significant, nevertheless low and indirect, effect between CA-IC-OP. Hence, competitive advantage mediates the relationship between intellectual capital and organisational performance.

Table 9 Mediation model

\begin{tabular}{|c|c|c|c|c|c|c|c|}
\hline \multicolumn{8}{|l|}{ Direct effect } \\
\hline Relation & $\begin{array}{l}\text { Std. } \\
\text { beta }\end{array}$ & $\begin{array}{l}\text { Std. } \\
\text { error }\end{array}$ & t-value & $\begin{array}{c}P \\
\text { values }\end{array}$ & $\begin{array}{l}95 \% \\
C I L L \\
\end{array}$ & $\begin{array}{c}95 \% \\
\text { CIUL } \\
\end{array}$ & \\
\hline $\begin{array}{l}\text { Competitive advantage } \rightarrow \\
\text { Intellectual capital }\end{array}$ & 0.206 & 0.066 & $3.112 * *$ & 0.002 & 0.678 & 0.806 & \\
\hline $\begin{array}{l}\text { Competitive advantage } \rightarrow \\
\text { Organisational performance }\end{array}$ & 0.085 & 0.046 & $1.845^{* *}$ & 0.066 & 0.162 & 0.012 & \\
\hline $\begin{array}{l}\text { Intellectual capital } \rightarrow \\
\text { Organisational performance }\end{array}$ & 0.743 & 0.039 & $19.12 * *$ & 0.000 & 0.317 & 0.107 & \\
\hline \multicolumn{8}{|l|}{ Indirect effect } \\
\hline $\begin{array}{l}\text { Competitive advantage } \rightarrow \\
\text { Intellectual capital } \rightarrow \\
\text { Organisational performance }\end{array}$ & 0.154 & 0.051 & $2.982 * *$ & 0.003 & 0.243 & 0.077 & Acepted \\
\hline
\end{tabular}

Note: $\quad * * p=0.001$

\section{Discussion and conclusions}

This research allows us to support a number of researches carried out in Mexico that have analysed the relationship between intellectual capital and organisational performance (Heredia and González, 2010; Mejía et al., 2014; De la Garza et al., 2015; SánchezGutiérrez et al., 2016; Ibarra-Cisneros and Hernandez-Perlines, 2018). The conclusions are heterogeneous, but by and large, they conclude the existence of this relation in different sectors of the economy and in a particular way, with certain dimensions of IC. In the case of the manufacturing sector, we concurred with Aguilera et al. (2014), who also carried out a similar exercise.

On the other hand, evidence showed that $\mathrm{HC}, \mathrm{SC}$ and $\mathrm{RC}$ have a positive influence on organisational performance in medium-sized Mexican manufacturing firms; out of them, $\mathrm{SC}$ is the most relevant, as it is fundamental for any organisation given that the policies, processes and procedures that are used by all the members of the firm are included here, 
additionally structural capital improves relational capital (Jardon and Martos, 2012). Studies at international level such as Chowdhury et al. (2018) indicated that SC has a considerable effect on organisational performance measured in financial terms. Furthermore, to the extent that SC indicators develop adequately inside the organisations, $\mathrm{HC}$ may be potentialised. In the same vein, investment in R\&D as well as in patents, use of IT and communication systems allow to be a catalyst of OP. Due to the type of goods produced by manufacturing firms, the development of SC becomes imperative, especially if there is intensive IT adoption in activities such as production of electronic, aerospace, automotive or medical devices. RC is also key for manufacturing companies, its influence is low nevertheless (Aguilasocho et al., 2015), and in other research findings this has not been relevant in comparison with other types of capital (Daou et al., 2014). In our results, RC has an influence on OP, which is supported by other studies (Khan and Terziovski, 2014); this indicates that strategic alliances, mergers, participation in business chambers, good relationships with other actors of society, but above all, a good relationship with clients and suppliers allows firms to perform better.

In the case of human capital, results verify what Bontis et al. (2018) and Smriti and Das (2018) established by pointing out that HC contributes to explain the firm's economic and organisational performance. However, in this paper, HC presented the weakest relation of the three dimensions.

From this follows that $\mathrm{HC}$ has not been sufficiently developed, hence such would be the main task for the organisations. Investing in education and training, improving motivation actions and generating commitment to the firm can be factors that allow promoting $\mathrm{HC}$ development.

Although the results indicated that competitive advantage mediates the relationship between intellectual capital and organisational performance, its strength is tenuous. This means that it is necessary for firms to continue increasing both the efforts to raise IC and to generate significant CA. Perhaps, the firms have not been able to find out what differentiates them from other companies in terms of costs, prices, quality, innovation and delivery times and this has affected the results of the study. The study by Cuevas et al. (2014) applied to manufacturing firms in the region of Aguascalientes, Mexico, established that there is a relation between intellectual capital and competitiveness. In this case, CA was not utilised as a dependent variable, but it allows verifying the indirect relation between both variables in our study. In like manner, the study by Zaparí et al. (2012) supports the relation between IC and CA for the case of manufacturing firms in the third largest region in Mexico.

Another factor may be that many of the companies are basically suppliers within a complex production chain in which their customers are long-lasting and unique on many occasions; therefore, they are not focused on turning to the final market. Another relevant finding was that neither the origin of the capital nor whether the firm exports are relevant for the interaction between IC and OP; therefore, only CA indirectly influences the relation between IC and OP.

Among the contributions that the results of this paper offer are the generation of knowledge about the state of intellectual capital in manufacturing firms in Mexico. In addition, IC acts indirectly with competitive advantage to positively affect OP. As well, the results of the investigation will allow comparing it with future studies. This way, interest will grow to research at greater depth the three analysed variables, not only in the national productive apparatus but also at a global scale. 
The theoretical implication of this research was to test the theory already analysed and referenced by many authors and to verify its acceptance in Mexican industry. While the practical implication will be in the future, once the information generated here is sent and disseminated among the CEOs and managers of the Mexican manufacturing sector as part of the commitments generated. Since it is important that information not only circulates among the academic sphere, but also reaches the most important link, which is, in this case, manufacturing firms.

The main limitation that was found in the development of the research was the difficulty in surveying CEOs and managers, which is understandable. Therefore, the entire number of individuals in the sample could not be reached, however the percentage accumulated was sufficient to attain the stated objective.

The future line of research will focus on specifically ascertaining how intellectual capital is developed in organisations, by studying and establishing best practices, a path can be outlined in order to help other organisations to maximise the intellectual capital they possess and to be the basis for the improved performance of any organisation.

\section{References}

Abdel, G. and Romo, D. (2004) 'Sobre el concepto de competitividad', Documentos de trabajo en estudios de competitividad, Centro de estudios de competitividad, ITAM, Distrito Federal, México.

Agostini, L., Nosella, A. and Filippini, R. (2017) 'Does intellectual capital allow improving innovation performance? A quantitative analysis in the SME context', Journal of Intellectual Capital, Vol. 18, No. 2, pp.400-418.

Aguilasocho, D., Galeana, E. and Peña, A. (2015) 'Impacto del Capital Intelectual en la Competitividad de las Pequeñas y Medianas Industrias Manufactureras de Morelia, Michoacán', Revista de Gestión Empresarial y Sustentabilidad, Vol. 1, No. 1, pp.1-19.

Aguilera, L., Hernández, O. and Colin, M. (2014) 'La relación entre el capital intelectual y los procesos de producción en la pyme manufacturera', Cuadernos del CIMBAGE, No. 16, pp.87-109.

Albright, S.C., Winston, W.L. and Zappe, C.J. (2008) Data Analysis \& Decision Making with Microsoft Excel, South-Western Cengage Learning, Mason, $\mathrm{OH}$.

Alfraih, M. (2018) 'Intellectual capital reporting and its relation to market and financial performance', International Journal of Ethics and Systems, Vol. 34, No. 3, pp.266-281.

Ali, M., Lei, S. and Wei, X-Y. (2018) 'The mediating role of the employee relations climate in the relationship between strategic HRM and organizational performance in Chinese Banks', Journal of Innovation \& Knowledge, Vol. 3, No. 3, pp.115-122.

Anderson, J. and Gerbing, D. (1988) 'Structural equation modeling in practice: a review and recommended two-step approach', Psychological Bulletin, pp.411-423.

Asiaei, A. and Jusoh, R. (2017) 'Using a robust performance measurement system to illuminate intellectual capital', International Journal of Accounting Information Systems, Vol. 26, No. 1, pp.1-19.

Asiaei, K., Jusoh, R. and Bontis, N. (2018) 'Intellectual capital and performance measurement systems in Iran', Journal of Intellectual Capital, Vol. 19, No. 2, pp.294-320.

Berumen, S. (2006) 'Una aproximación a los indicadores de la competitividad local y factores de la producción', Cuadernos de Administración, Vol. 19, No. 31, pp.145-163.

Bollen, L., Vergauwen, P. and Schnieders, S. (2005) 'Linking intellectual capital and intellectual property to company performance', Management Decision, Vol. 43, No. 9, pp.1161-1185.

Bontis, N. (1998) 'Intellectual capital: an exploratory study that develops measures and models', Management Decision, Vol. 36, No. 2, pp.63-76. 
Bontis, N., Chua Chong Keow, W. and Richardson, S. (2000) 'Intellectual capital and business performance in Malaysian industries', Journal of Intellectual Capital, Vol. 1, No. 1, pp. $85-100$.

Bontis, N., Ciambotti, M., Palazzi, F. and Sgro, F. (2018) 'Intellectual capital and financial performance in social cooperative enterprises', Journal of Intellectual Capital, Vol. 19, No. 4, pp.712-731.

Brooking, A. (1996) Intellectual Capital, International Thomson Business Press, London.

Bueno, E., Del Real, H., Fernández, P., Longo, M., Merino, C. and Murcia, C. (2011) Modelo Intellectus de Medición, Gestión e Información del Capital Intelectual (nueva versión actualizada), IADE, Universidad Autónoma de Madrid, Madrid.

Bueno, E., Salmador, P. and Longo-Somoza, M. (2014) 'Advances in the identification and measurement of Intellectual Capital and future developments in the Intellectual Capital research agenda: experience of the Intellectus Model and proposal of a synthetic index', Knowledge Management Research and Practice, Vol. 12, No. 3, pp.339-349.

Cabrilo, S. and Dahms, S. (2018) 'How strategic knowledge management drives intellectual capital to superior innovation and market performance', Journal of Knowledge Management, Vol. 22, No. 3, pp.621-648.

Calix, C., Vigier, H. and Briozzo, A. (2015) 'Capital intelectual y otros determinantes de la ventaja competitiva en empresas exportadoras de la zona norte de Honduras', Suma de Negocios, Vol. 6, No. 14, pp.130-137.

Cangur, S. and Ercan, I. (2015) 'Comparison of model fit indices used in structural equation modeling under multivariate normality', Journal of Modern Applied Statistical Methods, Vol. 14, No. 1, Article 14. Available online at: DOI: $10.22237 / \mathrm{jmasm} / 1430453580$

Carmines, E.G. and Zeller, R.A. (1979) Reliability and Validity Assessment, Vol. 17, Sage Publications, Beverly Hills.

Chang, C-C., Hung, S-W and Huang, S-Y. (2013) 'Evaluating the operational performance of knowledge-based industries: the perspective of intellectual capital', Qual Quant, Vol. 47, No. 3, pp.1367-1383.

Chin, W. (1998) 'The partial least square approach to structural equation modelling', in Marcoulides, G. (Ed.): Modern Methods for Business Research, Lawrence Erlbaum, Mahawah, United States, pp.295-369.

Chowdhury, L., Rana, T., Akter, M. and Hoque, M. (2018) 'Impact of intellectual capital on financial performance: evidence from the Bangladeshi textile sector', Journal of Accounting \& Organizational Change, Vol. 14, No. 4, pp.429-454.

Chu, Y., Lin, L., Yu, P., Hsiung, H. and Liu, T. (2006) 'Intellectual capital: an empirical study of ITRI', Technological Forecasting and Social Change, Vol. 73, No. 1, pp.886-902. Available online at: www.sciencedirect.com

Cleary, P. and Quinn, M. (2016) 'Intellectual capital and business performance: an exploratory study of the impact of cloud-based accounting and finance infrastructure', Journal of Intellectual Capital, Vol. 17, No. 2, pp.255-278.

Cricelli, L., Greco, M. and Grimaldi, M. (2014) 'An overall index of intellectual capital', Management Research Review, Vol. 37, No. 10, pp.880-901.

Cuevas, H., Aguilera, L. and González, M. (2014) 'La influencia de la innovación y el capital intelectual en la competitividad de las PYMES manufactureras de Aguascalientes', Red Internacional de Investigadores en Competitividad, Vol. 8, No. 1, pp.1638-1655.

Dabić, M., Lažnjak, J., Smallbone, D. and Švarc, J. (2018) 'Intellectual capital, organisational climate, innovation culture, and SME performance: evidence from Croatia', Journal of Small Business and Enterprise Development.

Daou, A., Karuranga, E. and Su, Z. (2014) 'Towards a better understanding of intellectual capital in Mexican SMEs', Journal of Intellectual Capital, Vol. 15, No. 2, pp.316-332. 
De la Garza, H., Zerón, M. and Sánchez, Y. (2015) 'El capital Intelectual y su Importancia en la Competitividad de las Pequeñas y Medianas Empresas del dentro del Estado de Tamaulipas, México', Revista Nacional de Administración, Vol. 6, No. 1, pp.63-80.

Delaney, J. and Huselid, M. (1996) 'The impact of human resource practices on perceptions organizational performance', Academy of Management Journal, Vol. 39, No. 4, pp.949-969.

Diamantopoulos, A. and Winklhofer, H.M. (2001) 'Index construction with formative indicators: an alternative to scale development', Journal of Marketing Research, Vol. 38, pp.269-277.

Díez, J., Ochoa, M., Prieto, B. and Santidrián, A. (2010) 'Intellectual capital and value creation in Spanish firms', Journal of Intellectual Capital, Vol. 11, No. 3, pp.348-367.

Drost, E.A. (2011) 'Validity and reliability in social science research', Educ Res Perspect, pp.105-123.

Edvinsson, L. and Malone, M.S. (1997) Intellectual Capital: Realizing Your Company's True Value by Finding its Hidden Brainpower, Harper Business, New York, NY.

Esser, K., Hillenbrand, W. and Meyer-Stamer, J. (1996) 'Competitividad Sistémica: Nuevo Desafío a las empresas y a la política', Revista de la CEPAL, Vol. 59, agosto, pp.39-52.

Fernández-Jardon, C. and Martos, M. (2016) 'Intellectual capital and competitive advantages in natural resource-based SMEs in Latin America', Innovar, Vol. 26, No. 60, pp.117-132.

Ferreira, J. and Fernandes, C. (2017) 'Resources and capabilities' effects on firm performance: what are they?', Journal of Knowledge Management, Vol. 21, No. 5, pp.1202-1217.

Fornell, C. and Larcker, D.F. (1981) 'Evaluating structural equation models with unobservable variables and measurement error', Journal of Marketing Research, Vol. 18, No. 1, pp.39-50.

Galabova, L. and McKie, L. (2013) 'The five fingers of my hand: human capital and well-being in SMEs', Personnel Review, Vol. 42, No. 6, pp.662-683.

Gashi, L.M., Požega, Ž. and Crnković, B. (2017) 'Employees' individual values as a source of human capital', Economic Research-EkonomskaIstrazivanja, Vol. 30, No.1, pp.1057-1072.

Ginesti, G., Caldarelli, A. and Zampella, A. (2018) 'Exploring the impact of intellectual capital on company reputation and performance', Journal of Intellectual Capital, Vol. 19, No. 5, pp.915-934.

Gogan, L.M., Artene, A., Sarca, I. and Draghici, A. (2016) 'The impact of intellectual capital on organizational performance', Procedia - Social and Behavioral Sciences, Vol. 221, pp.194-202.

Goldsby, M.G., Kreiser, P.M., Kuratko, D.F., Bishop, J.W. and Hornsby, J.S.(2018) 'Social proactiveness and innovation: the impact of stakeholder salience on corporate entrepreneurship', Journal of Small Business Strategy, Vol. 28, No.2, pp.1-15.

Hair, J., Hult, G., Ringle, M. and Sarstedt, M. (2011) 'PLS-SEM: indeed, a silver bullet', Journal of Marketing Theory and Practice, Vol. 2, No. 19, pp.139-151.

Hair, J., Hult, G., Ringle, C. and Sarstedt, M. (2017) A Primer on Partial Least Square Structural Equation Modeling (PLS-SEM), Sage, California, United States.

Hair, J., Sarstedt, M., Hopkins, L. and Kuppelwieser, V. (2014) 'Partial least squares structural equation modeling (PLS-SEM): an emerging tool in business research', European Business Review, Vol. 26, No. 2, pp.106-121.

Hamdan, A. (2018) 'Intellectual capital and firm performance: differentiating between accounting based and market-based performance', International Journal of Islamic and Middle Eastern Finance and Management, Vol. 11, No. 1, pp.139-151.

Han, Y. and Li, D. (2015) 'Effects of intellectual capital on innovative performance: the role of knowledge-based dynamic capability', Management Decision, Vol. 53, No. 1, pp.40-56.

Henseler, J., Ringle, C.M. and Sarstedt, M. (2015) 'A new criterion for assessing discriminant validity in variance-based structural equation modeling', Journal of the Academy of Marketing Science, Vol. 43, No. 1, pp.115-135.

Heredia, J. and González, M. (2010) 'Medición de los Capitales Intelectuales Visibles e Invisibles', Conciencia Tecnológica, No. 40, julio-diciembre, pp.10-14. 
Ibarra-Cisneros, M. and Hernández-Perlines, F. (2018) 'Intellectual capital and organization performance in the manufacturing sector of Mexico', Management Decision, Vol. 56, No. 8, pp.1818-1834.

Instituto Nacional de Estadística y Geografía (INEGI) (2018a) Encuesta mensual de la industria manufacturera. Available online at: https://datos.gob.mx/busca/dataset/encuesta-mensual-dela-industria-manufacturera

Instituto Nacional de Estadística y Geografía (INEGI) (2018b) Directorio estadístico nacional de unidades económicas. Available online at: www.beta.inegi.org.mx/app/mapa/denue/

Jain, P., Vyas, V. and Roy, A. (2017) 'Exploring the mediating role of intellectual capital and competitive advantage on the relation between CSR and financial performance in SMEs', Social Responsibility Journal, Vol. 13, No. 1, pp.1-23.

Jardon, C. and Martos, M. (2012) 'Intellectual capital as competitive advantage in emerging clusters in Latin America', Journal of Intellectual Capital, Vol. 13, No. 4, pp.462-481.

Jurksiene, L. and Pundziene, A. (2016) 'The relationship between dynamic capabilities and firm competitive advantage: the mediating role of organizational ambidexterity', European Business Review, Vol. 28, No. 4, pp.431-448.

Kamukama, N. (2013) 'Intellectual capital: company's invisible source of competitive Advantage', Competitiveness Review. An International Business Journal, Vol. 23, No. 3, pp.260-286.

Kamukama, N., Ahiauzu, A. and Ntayi, J. (2011) 'Competitive advantage: mediator of intellectual capital and performance', Journal of Intellectual Capital, Vol. 12, No. 1, pp.152-164.

Kang, S. and Snell, S. (2009) 'Intellectual capital architectures and ambidextrous learning: a framework for human resource management', Journal of Management Studies, Vol. 46, No. 1, pp.65-92.

Kengatharan, N. (2019) 'A knowledge-based theory of the firm: Nexus of intellectual capital, productivity and firms' performance', International Journal of Manpower.

Khalique, M., Bontis, N., Abdul Nassir bin Shaari, J. and Hassan Md. Isa, A. (2015) 'Intellectual capital in small and medium enterprises in Pakistan', Journal of Intellectual Capital, Vol. 16, No. 1, pp.224-238.

Khan, Y. and Terziovski, M. (2014) 'The effects of intellectual capital on performance in Australian small and medium enterprises (SMEs)', Proceedings of Australia and New Zealand Academy of Management, December 3, pp.1-29.

Kianto, A., Hurmelinna-Laukkanen, P. and Ritala, P. (2010) 'Intellectual capital in service- and product oriented companies', Journal of Intellectual Capital, Vol. 11, No. 3, pp.305-325.

Kock, N. (2012) WarpPLS 3.0 User Manual, ScriptWarp Systems, Laredo, Texas.

Kong, E. and Prior, D. (2008) 'An intellectual capital perspective of competitive advantage in nonprofit organization', International Journal of Nonprofit and Voluntary Sector Marketing, Vol. 13, pp.119-128.

Lee, J-W. and Lee, H. (2018) 'Human capital and income inequality', Asian Development Bank Institute Working Paper Series, Routledge, Vol. 810, No. 0, pp.1-29.

Li, J. and Yu, D. (2018) 'The path to innovation: the antecedent perspective of intellectual capital and organizational character', Frontiers in Psychology, Vol. 9 (December), pp.1-18. Available online at: doi: 10.3389/fpsyg.2018.02445

Li, S., Ragu-Nathan, B., Ragu-Nathan, T.S. and Subba Rao, S. (2006) 'The impact of supply chain management practices on competitive advantage and organizational performance', Omega, Vol. 34, No. 2, pp.107-124.

Liang, C., Chen, T. and Lin, Y. (2013) 'How do different business models affect intellectual capital?', Journal of Intellectual Capital, Vol. 14, No. 2, pp.176-191.

Liebowitz, J. and Suen, C. (2000) 'Developing knowledge management metrics for measuring intellectual capital', Journal of Intellectual Capital, Vol. 1, No. 1, pp.54-67.

Lynn, L. and Dallimore, P. (2004) 'Intellectual capital: management attitudes in service industries', Journal of Intellectual Capital, Vol. 5, No. 1, pp.181-194. 
Mejía, Y., Rodríguez, M. and Hernández, A. (2014) 'Importancia Estratégica del Capital Intelectual en la Industria Manufacturera de la Región Sureste del Estado de Coahuila, México', Revista Internacional Administración y Finanzas, Vol. 7, No. 4, pp.93-106.

Mercado, P., Nava, R. and Demuner, M. (2012) 'Presencia de los intangibles y el capital intelectual en la competitividad país-empresa', en Mercado, P. and Cernas, D. (coords): El capital intelectualen las organizaciones, UAEMEX, p.229.

Meyers, L.S., Gamst, G. and Guarino, A.J. (2006) Applied Multivariate Research: Design and Interpretation, Sage, Thousand Oaks, CA.

Montejano, S. and López, G. (2013) 'Impacto del Capital Intelectual en la Innovación en Empresas: Una Perspectiva de México', TEACS, Vol. 6, No. 13, Julio-Diciembre. Available online at: https://dialnet.unirioja.es/servlet/articulo?codigo $=4736447$

Moon, Y. and Kym, H. (2006) 'A model for the value of intellectual capital', Canadian Journal of Administrative Sciences, Vol. 23, No. 3, pp.253-269.

Nadeem, M., Gan, C. and Nguyen, C. (2018) 'The importance of intellectual capital for firm performance: evidence from Australia', Australian Accounting Review, Vol. 28, No. 3, pp.334-344.

Nahapiet, J. and Ghoshal, S. (1998) 'Social capital, intellectual capital, and the organizational advantage', Academy of Management Review, Vol. 23, No. 2, pp.242-266.

Pedro, E., Leitão, J. and Alves, H. (2018) 'Intellectual capital and performance: taxonomy of components and multi-dimensional analysis axes', Journal of Intellectual Capital, Vol. 19, No. 2, pp.407-452.

Peng, T.J.A., Pike, S. and Roos, G. (2007) 'Intellectual capital and performance indicators: Taiwanese healthcare sector', Journal of Intellectual Capital, Vol. 8, No. 3, pp.538-556.

Phusavat, K., Comepa, N., Sitko-Lutek, A. and Ooi, K. (2011) 'Interrelationships between intellectual capital and performance', Industrial Management \& Data Systems, Vol. 111, No. 6, pp.810-829.

Pirozzi, M.G. and Ferulano, G.P. (2016) 'Intellectual capital and performance measurement in healthcare organizations: an integrated new model', Journal of Intellectual Capital, Vol. 17, No. 2, pp.320-350.

Pitchayadol, P., Hoonsopon, D., Chandrachai, A. and Triukose, S. (2018) 'Innovativeness in Thai family SMEs: An exploratory case study', Journal of Small Business Strategy, Vol. 28, No. 281, pp.38-48.

Porter, M.E. (1980) Competitive Strategy: Techniques for Analyzing Industries and Competitors, The Free Press, New York.

Porter, M.E. (1991) 'Towards a dynamic theory of strategy', Strat. Mgmt. J., Vol. 12, pp.95-117.

PROMEXICO (2018) Information about economics sector of Mexico. Available online at: http://www.promexico.mx/en/mx/sectores

Ramírez, O. and Duván, E. (2007) 'Capital Intelectual. Algunas Reflexiones Sobre su Importancia en las Organizaciones', Pensamiento \& Gestión, Vol. 23, No. 1, pp.131-152. Available online at: http://www.redalyc.org/articulo.oa?id $=64602306$

Ringle, C.M., Wende, S. and Becker, J-M. (2015) SmartPLS 3, SmartPLS GmbH, Boenningstedt. Available online at: http://www.smartpls.com

Ritchie, B. (2002) Foreign Direct Investment and Intellectual Capital Formation in Southeast Asia, OECD Development Centre Working Papers, No. 194, OECD Publishing, Paris.

Roldán, J.L. and Sánchez-Franco, M.J. (2012) 'Variance-based structural equation modeling: Guidelines for using partial least squares in information systems research', in Mora, M., Gelman, O., Steenkamp, A. and Raisinghani, M. (Eds): Research Methodologies, Innovations and Philosophies in Software Systems Engineering and Information Systems, IGI Global, Hershey, pp.193-221.

Roos, G. and Roos, J. (1997) 'Measuring your company's intellectual performance', Long Range Planning, Vol. 30, No. 3, pp.413-426. 
Rua, O., França A. and Fernández Ortiz, R. (2018) 'Key drivers of SMEs export performance: the mediating effect of competitive advantage', Journal of Knowledge Management, Vol. 22, No. 2, pp.257-279.

Rusu, V.D. and Roman, A. (2018) 'An empirical analysis of factors affecting competitiveness of C.E.E. countries', Economic Research-EkonomskaIstrazivanja, Routledge, Vol. 9664, pp.1-16.

Sánchez-Gutiérrez, J., Mejía-Trejo, J., Vargas-Barraza, J. and Vazquez-Avila, G. (2016) 'Intellectual capital, impact factor on competitiveness: manufacturing industry SMEs in Mexico', Measuring Business Excellence, Vol. 20, No. 1, pp.1-11.

Sánchez Medina, A., Melián, A. and Hormiga, E. (2007) 'El Concepto del Capital Intelectual y sus Dimensiones', Investigaciones Europeas de Dirección y Economía de la Empresa, Vol. 13, No. 2, mayo-agosto, pp.97-111.

Scarabino, J., Biancardi, G. and Blando, A. (2007) 'Capital intelectual', Invenio, Vol. 10, No. 19, pp.59-71.

Schilke, O. (2014) 'On the contingent value of dynamic capabilities for competitive advantage: the nonlinear moderating effect of environmental dynamism', Strategic Management Journal, Vol. 35, No. 2, pp.179-203.

Seetharaman, A., Lock, T., Low, K. and Saravanan, A.S. (2004) 'Comparative justification on intellectual capital', Journal of Intellectual Capital, Vol. 5, No. 4, pp.522-539.

Seleim, A., Ashour, A. and Nick, B. (2004) 'Intellectual capital in Egyptian software firms', The Learning Organization, Vol. 11, No. 4/5, pp.332-346.

Sharabati, A.A.A., Naji Jawad, S. and Bontis, N. (2010) 'Intellectual capital and business performance in the pharmaceutical sector of Jordan', Management Decision, Vol. 48, No. 1, pp.105-131.

Sireci, S.G. (1998) 'The construct of content validity', Social Indicators Research, Vol. 45, No. $1 / 3$, pp.83-117.

Sirmon, D., Gove, S. and Hitt, M. (2008) 'Resource management in dyadic competitive rivalry: the effects of resource bundling and deployment', Academy of Management Journal, Vol. 51, No. 5, pp.919-935.

Smriti, N. and Das, N. (2018) 'The impact of intellectual capital on firm performance: a study of Indian firms listed in COSPI', Journal of Intellectual Capital, Vol. 19, No. 5, pp.935-964.

Ståhle, P., Ståhle, S. and Aho, S. (2011) 'Value added intellectual coefficient (VAIC): a critical analysis', Journal of Intellectual Capital, Vol. 12, No. 4, pp.531-551.

Stieg, P., Cesinger, B., Apfelthaler, G., Kraus, S. and Cheng, C.F. (2018) 'Antecedents of successful internationalization in family and non-family firms: how knowledge resources and collaboration intensity shape international performance', Journal of Small Business Strategy, Vol. 28, No. 1, pp.14-27.

Suraj, O.A. and Bontis, N. (2012) 'Managing intellectual capital in Nigerian telecommunications companies', Journal of Intellectual Capital, Vol. 13, No. 2, pp.262-282.

Sveiby, K.E. (1997) The New Organizational Wealth Managing and Measuring Knowledge, Berrett-Koehler Publishers Inc., San Francisco, CA.

Torres, A., Santos-Ferraz, S. and Santos-Rodrigues, H. (2018) 'The impact of knowledge management factors in organizational sustainable competitive advantage', Journal of Intellectual Capital, Vol. 19, No. 2, pp.453-472.

Tovstiga, G. and Tulugurova, E. (2007) 'Intellectual capital practices and performance in Russian enterprises', Journal of Intellectual Capital, Vol. 8, No. 4, pp.695-707.

Tovstiga, G. and Tulugurova, E. (2009) 'Intellectual capital practices: a four-region comparative study', Journal of Intellectual Capital, Vol. 10, No. 1, pp.70-80.

Tseng, C. and James, Y. (2005) 'Intellectual capital and corporate value in an emerging economy: empirical study of Taiwanese manufacturers', $R \& D$ Management, Vol. 35, No. 2, pp.187-201. 
Ugalde-Blinda, N., Balbastre-Benavent, F., Canet-Giner, T. and Escribá-Carda, N. (2014) 'The role of intellectual capital and entrepreneurial characteristics as innovation drivers', Innovar, Vol. 24, No. 53, pp.41-60.

Uriona, M., Coehlo, L. and Murcia, C. (2013) 'El Capital Intelectual como Recurso para Generar Capacidades Dinámicas en las Pymes en el Nuevo Entorno de Crisis Económica', Economía Industrial, Vol. 388, No. 1, pp.23-34.

Vallejo, P.M. (2013) 'El Análisis Factorial en la construcción e interpretación de tests, escalas y Cuestionarios', Working Paper, September 15, Facultad de Ciencias Humanas y Sociales, Universidad Pontificia Comillas, Madrid.

Vehkalahti, K. (2000) Reliability of Measurement Scales: Tarkkonen's General Method Supersedes Cronbach's Alpha, Dissertation, University of Helsinki, Finnish Statistical Society, Helsinki, p.116.

Walecka, A. (2018) 'Analysis of the relationship between the enterprise and the environment in the context of managing the relational capital', Management, Vol. 22, No. 2, pp.25-41.

Wang, W.Y. and Chang, C. (2005) 'Intellectual capital and performance in causal models: evidence from the information technology industry in Taiwan', Journal of Intellectual Capital, Vol. 6, No. 2, pp.222-236.

Wang, Z., Wang, N. and Liang, H. (2014) 'Knowledge sharing, intellectual capital and firm performance', Management Decision, Vol. 52, No. 2, pp.230-258.

Yaseen, S., Dajani, D. and Hasan, Y. (2016) 'The impact of intellectual capital on the competitive advantage: applied study in Jordanian telecommunication companies', Computers in Human Behavior, Vol. 62, No. 1, pp.168-175.

Youndt, M.A., Subramaniam, M. and Snell, S.A. (2004) 'Intellectual capital profiles: an examination of investments and returns', Journal of Management Studies, Vol. 4, No. 2, pp.335-361.

Yu, H.C., Kuo, L. and Kao, M.F. (2017) 'The relationship between CSR disclosure and competitive advantage', Sustainability Accounting, Management and Policy Journal, Vol. 8, No. 5, pp.547-570.

Zaparí, G., Ortíz, M. and Ornelas, A. (2012) 'El incremento de la competitividad en las PyMEs manufactureras de Guadalajara a través del desarrollo del capital intelectual', Red Internacional de Investigadores en Competitividad, Vol. 6, No. 1, pp.1429-1445.

Zhang, M., Qi, Y., Wang, Z., Pawar, K.S. and Zhao, X. (2018) 'How does intellectual capital affect product innovation performance? Evidence from China and India', International Journal of Operations and Production Management, Vol. 38, No. 3, pp.895-914. 